\title{
Are Graduates from the Arts-Related Academic Disciplines More Productive than those from the Science-Related Disciplines?
}

\author{
Victoria Kakooza ${ }^{1}$, Robert Wamala ${ }^{2}$, James Wokadala ${ }^{3} \&$ Thomas Bwire ${ }^{4}$ \\ ${ }^{1} \mathrm{PhD}$ Student, School of Statistics, College of Business and Management Science, Makerere University. Kampala, \\ Uganda \\ ${ }^{2}$ Deputy Director, Directorate of Research and Graduate Training, Makerere University,Kampala, Uganda \\ ${ }^{3}$ Lecturer- School of Statistics, College of Business and Management Science, Makerere University.Kampala, \\ Uganda \\ ${ }^{4}$ Economic Reaserch Function,Bank of Uganda, Uganda \\ Correspondence: Victoria Kakooza, PhD Student, School of Statistics, College of Business and Management Science, \\ Makerere University. Kampala, Uganda. E-mail: victoriakakooza@gmail.com
}

Received: May 22, 2019

doi:10.5430/ijhe.v8n3p226
Accepted: June 12, 2019

Online Published: June 13, 2019

\begin{abstract}
The experiences of employees from developed countries affirm that those from science/ technology-related disciplines benefit more through more technological inventions, than those from the Arts/ Humanities-related disciplines. The study utilizes statistical data of higher education graduates to determine a causal link between graduates from the two fore mentioned academic disciplines, and labour productivity in the developing country of Uganda. The data from 1985 to 2017 were analysed using the Vector Error Correction model, and revealed that arts graduates were-as productive as the science graduates. The findings also show the existence of long-term relationship between academic discipline and labour productivity, as well as a bi-causality between the variables under study.
\end{abstract}

Keywords: female graduates, male graduates, labour productivity, Uganda, vector error correction model

\section{Introduction}

For a period of time, the Arts and Humanities have been devalued in the society and in academia, believing that science related disciplines are more superior to the Arts and humanities (Kiani 2011; Pelser, 2016). Countries like India that have large labour forces with relatively low economic growth, continue to affirm that quantity of the labour force is not enough, but quality is (Moeller, 2018). This concept has been exhibited in the higher education sector where Arts and Humanities have lower requirements for student entry in higher education institutions of developing countries, than the Science/Technology disciplines (Assaad, \& Abdalla, 2018). The question is: Is this preference is rooted in their contribution to labour productivity in the labour markets in developing countries?

Uganda has not been immune to labour productivity in the labour markets. The science and technology disciplines have been promoted by the government, several donor agencies, and private funders. Despite the less importance given to the Arts and humanities disciplines, most students that join the higher education institutions do not opt for disciplines which are not science based. The Arts and humanities hence have the highest number of enrolments in the higher education sector in Uganda (MES, 2017). The question is whether is whether the Arts and humanities disciplines produce graduates that are more productive than the science/ technology disciplines. Does this gap exist for labour markets in developing countries-like-Uganda, whose economy is slowly becoming less agrarian?

Study disciplines forms -part of the distinguishing features of higher education graduates in labour market productivity. The education sector provides both skills and general specific skills for the various disciplines and (Wamboye, Adekola, \& Sergi, 2015). Combining these skills with social skills, higher education graduates are expected to be innovative, with the ability to generate employment(Bridgstock,2019). Some developed economies such as, China, Pakistan and Turkey have substantially benefited from higher education (Chaudhary, Iqbal, \& Gillani, 2009; Kui, 2006; Yurtkuran \& Terzi, 2015) However, some researchers have found no evidence of lower rewards of arts discipline in the labour market compared to their counterparts (Cameron, 2019; Hill \& Davidson, 2019; Hill, \& Pisacreta, (2019). As such, current research works and other efforts have been geared towards clarifying this 
aspect and strengthening the importance of arts and humanities in the developed world (Cameron, 2019). This study intends to contribute to this world of knowledge.

This study provides an empirical insight as to whether graduates from science- related disciplines are more productive than those from the arts- related disciplines in the developing country of Uganda.-

\subsection{Higher Education in Uganda}

The higher education sector in Uganda has undergone various reforms since 1922 when Makerere University was established ((Musisi \& Muwanga, 2003), that include; the introduction/accreditation of new programs: modification and upgrading of old programs; and the establishment of more public and private institutions(NCHE, 2016). These reforms have-produced a diversity of graduates from different disciplines, ready for the labour market. The student enrolments in the broader categories of Arts/ Humanities and Science/ Technology in the whole higher education sector in Uganda, are illustrated in Figure 1.

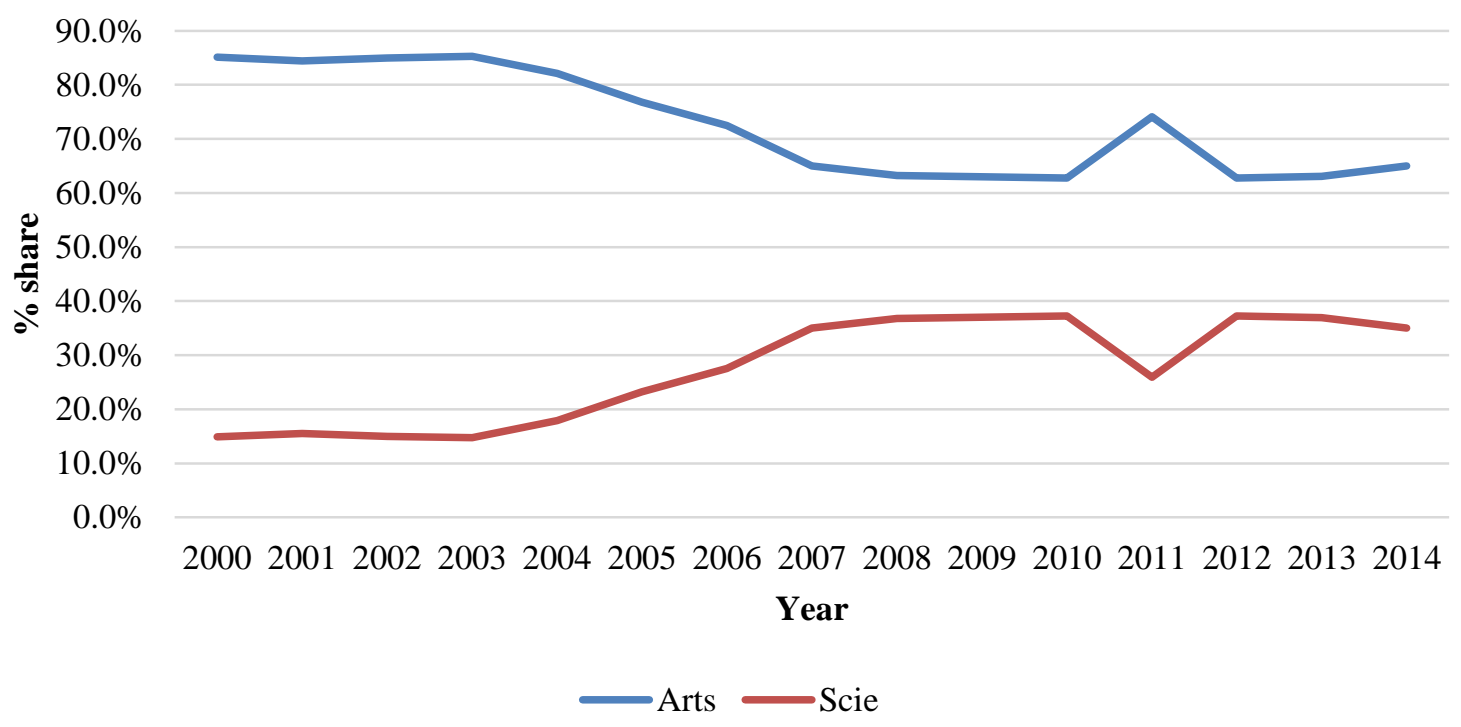

Figure 1. Higher education student Enrolments by Discipline (Source: MES, 2018)

Figure 1 shows that the percentage share of Higher education student enrolments in the science/Technology disciplines has averagely increased over the years. This has narrowed the gap between science/Technology and the arts/humanities academic disciplines and could be attributed to the increased Government and donor support for students studying science/Technology disciplines. The question is whether their value addition in the labour market has followed suit.

\section{Literature Review}

Marx's (2000) labour productivity theory of defines 'labour productivity' as when value is added during the working process. He further highlights that production is not sufficient without value addition of workers. This concept has been ignored by researchers in the labour market possibly due to lack of data. The majority have centred on GDP per person employed and GDP per worker to explain the productivity of workers (Byrne \& Corrado, 2017). Since education improves innovativeness, productivity, and adaptation of technology (Hanushek and Woessmann, 2007; Aghion et al., 2009) the current study seeks to employ Marx's (2000) theory of labour productivity and fill this gap.

It should be noted that different labour markets require different skills to adequately perform job tasks, hence; some graduates are more productive than others in different countries (Antonelli \& Fassio, 2015; De Grip, Van Loo, \& Mayhew, 2002). For example, Dalmon, et al. (2019) found that students offering Science, Technology, Engineering, and Mathematics (STEM) disciplines had higher gains in terms of earnings and employment than those from the humanities sector in Brazil. On the other hand, Borisova, (2019) found out that non-field specific graduates, of which majority are from the Arts and humanities disciplines; often obtain employment faster than those from the field-specific disciplines. This suggests that the non-field specific graduates tend have more experience than that of field-specific graduates which is a vital in producing higher productivity levels. This further implies that, high productivity of levels in the early years of most Arts and humanities graduates is expected than from their counterparts in the science and technology disciplines. This however may change over time (Borisova, 2019). This 
highlights the relevance of time frame in the impact of productivity by all disciplines; necessitating a time series methodology to capture both short term and long term effects. Morrissey (2013) also continues to assert the importance, relevance and value of those liberal Arts graduates. The value of the liberal Arts graduates is said to be inherent value that warrants recognition and support. This value, however, needs to be empirically proven in the labour markets.

In trying to explain the lower productivity levels of graduates, Ntemngweh, (2016) cited that many university graduates from the arts and humanities discipline end up settling for employment that is not related to their disciplines. These graduates tend to work in positions that do not align to their course of study. It was evidenced in the UK that of all job posts meant for STEM disciplines, 35\% were occupied by non-STEM employees, while $15 \%$ of all non-STEM jobs were occupied by employees of STEM disciplines (Grinis, 2019). Such education-job placement is also seen in other developing countries including Ntemngweh, (2016) in Cameroon; and Pitan, \& Adedeji (2012) in Nigeria. Productivity and pathways of career may be hindered by such horizontal mis-matches of the labour market and between employees' field of study and occupation impacts greatly on their productivity. This is said to be true for other disciplines like the social sciences (Hur, Maurer, \& Hawley (2019).

\section{Methodology}

This study bases the empirical analysis on the Vector Error Correction model (VECM) in order to compare value added productivity of labour for higher education graduates from the Arts and Science academic disciplines in Uganda.-VECM models are used for its advantages in studying bi-causality of more than one variable; and regress lagged values of the variables (Juselius, 2006). Regressing the lagged values of graduates was seen as a suitable regression, since most graduates do not start work immediately. The VECM model also has ability to study both short run and long run dynamics of the impact between variables, which is of interest in the study. Prior to all the regressions, unit root tests (using the ADF test), optimum lag selection, and the Johansen co-integration tests were carried out, in order to establish the existence of stationarity, optimum lag, and co-integration of the variables, respectively. The study analyzed the above using a combination of Ms-Excel, Eviews and STATA software.

Annual secondary data was obtained from World Bank indicators and from administrative data of the largest three public universities in Uganda. Data for higher education graduates from the from the Arts and Science academic disciplines was obtained from Kyambogo University (KYU); Makerere University (MUK), as well as Mbarara University of Science and Technology (MUST),Secondary data on Gross capital formation, value added productivity of labour, and labour force was obtained from the World Bank database. Gross capital formation per person employed was computed by dividing it by the labour force, over the same period. Econometric analyses were mainly conducted using E- views software.

\subsection{Model Specification}

The VECM is also the restricted Vector autocorrelation Model (VAR); includes the Error correction Term (ECT). The ECT shows how variables return to equilibrium in the long run (Juselius, 1991, Johansen, 1995). Therefore the VECM model system takes the form in equation 2.

$$
\Delta x_{t}=v+\Pi x_{t-1}+\sum_{i=1}^{p-1} \Phi_{i}^{*} \Delta x_{t-i}+\varepsilon_{t}
$$

Where $\Pi=-\left(I-\boldsymbol{\Phi}_{1}-\boldsymbol{\Phi}_{2}, \ldots,-\boldsymbol{\Phi}_{\mathrm{p}}\right)=-\boldsymbol{\Phi}(1) ; I$ is an identity matrix; $\Phi_{j}^{*}=-\sum_{i=j+1}^{p} \Phi_{i} ; \mathrm{j}=1, \ldots, \mathrm{p}-1$

Where Rank $(\Pi)=\mathrm{m} ; 0<\mathrm{m}<\mathrm{k}$; $\Pi$ (a k x k matrix) is considered equal to $\alpha \beta^{\prime}$, with $\alpha$ being a (k x m) matrix of Eigen values, $\mathrm{m}$, that are co-integrating vectors; and $\beta$ being a $(\mathrm{k} \mathrm{x} \mathrm{m})^{\prime}$ matrix of eigen values , $\mathrm{m}$, that are adjusting vectors. $\Pi x_{t-1}$ represents the lagged error-correction term that explains the long-run relationship while $\sum_{i=1}^{p-1} \Phi_{i}^{*} \Delta x_{t-i}$ explains the short-run relationship between the variables; $\mathrm{i}=1, \ldots, \mathrm{k}-1$ is the number of optimal lags; $\Delta$ is the first difference; $\Phi_{i}^{*}$ is a matrix of coefficients that explain the short-run dynamics in the system (Juselius, 2006).

In combination to this, the Cobb- Douglas model (Solow, 1957) was augmented to incorporate the academic discipline of the graduates. in equation 1 .

$$
Y / L=A(K / L)^{\alpha} h^{1-\alpha}
$$

Where $\mathrm{Y}$ is the output; $\mathrm{h}$ is human capital; $\mathrm{L}$ is labour force; $\mathrm{K}$ is physical output; and $\mathrm{A}$ is the technology (TFP); $\alpha$ is the capital elasticity of output.

Augmenting equation 1 and taking natural logarithms results in equation 2

$$
\ln (\mathrm{Y} / \mathrm{L})=\alpha_{0}+\alpha_{k} \ln \left(\frac{K}{L}\right)+\alpha_{h A} \ln \left(h_{A}\right)+\alpha_{h S} \ln \left(h_{S}\right)
$$


Where Y/L represents labour productivity; $\beta_{0}$ is the constant; $\beta_{k}$ and $\beta_{h}$ areincreases in the percentage of labour productivity that result in a one percent increase in the independent variables; A, S, represents Arts and Science graduates respectively.

Transforming equation 2 into a VECM system, gives rise to equations3, 4, 5, and 6.

$\Delta \operatorname{InVAdW} \mathrm{W}_{t}=$

$\delta_{1}+\varphi_{1} \hat{\varepsilon}_{t-1}+\sum_{p-1}^{k} \delta_{11 p} \Delta \operatorname{InVAdW} \operatorname{VAd}_{t-p}+$

$\sum_{p-1}^{k} \delta_{12 p} \Delta \operatorname{In} \mathrm{GCFW}_{t-p}+\sum_{p-1}^{k} \delta_{12 p} \Delta$ Arts $+\sum_{p-1}^{k} \delta_{12 p} \Delta \operatorname{InSc}_{t-p}+v_{1 t}$

$\triangle \operatorname{InGCFW} W_{t}=$

$\delta_{2}+\varphi_{1} \hat{\varepsilon}_{t-1}+\sum_{p-1}^{k} \delta_{21 p} \Delta \operatorname{InGDP} P_{t-p}+$

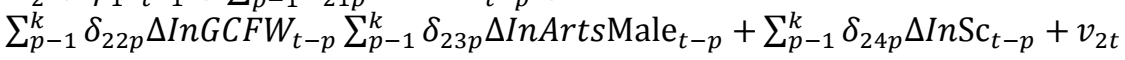

$\Delta \operatorname{In} \operatorname{Arts}_{t}=$

$\delta_{3}+\varphi_{1} \hat{\varepsilon}_{t-1}+\sum_{p-1}^{k} \delta_{31 p} \Delta \operatorname{InGDP} P_{t-p}+$

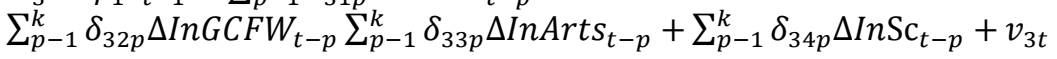

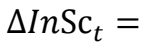

$\delta_{4}+\varphi_{1} \hat{\varepsilon}_{t-1}+\sum_{p-1}^{k} \delta_{41 p} \Delta \operatorname{InGDP} P_{t-p}+$

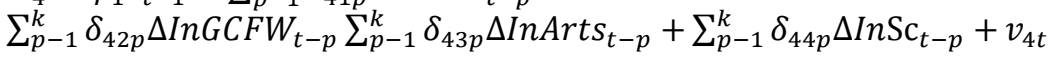

Where $\mathrm{k}$ is the optimal lag length, $\Delta$ first difference operator, , $\hat{\varepsilon}_{t-1}$ are error terms; VAdW is value added productivity of labour; GCFW is the Gross capital Formation per worker Arts and Sc shows graduates from the Arts and Science academic disciplines respectively.

\subsection{Prior Tests}

\section{Stationarity test}

The study uses the Augmented Dick-Fuller (ADF)(1979) test, to test for the stationarity or existence of unit roots in the trend of the variables. The test takes a linear regression form of:

$$
\Delta y_{t}=\alpha_{0}+\gamma y_{t-1}+\alpha_{2} t+\sum_{i=1}^{k} \alpha_{i} \Delta y_{t-1}+\varepsilon_{t}
$$

Where $\alpha_{0}$ is the intercept; $\mathrm{t}$ is the linear trend; $\Delta$ is the first difference; $i$ is the lag value; $\varepsilon$ is the error term.

The test is done under the following hypotheses:

$\mathrm{H}_{0}$ : the variable has unit root (is non-stationary) of order I (1).

$\mathrm{H}_{1}$ : the variable has no unit root (is stationary) at level I (0).

\section{Test for Co-integration}

This restricts a dynamic model and is applied on more than one variable. In other words, the test is used to determine the presence of co-integration among variables and also detect the number of co-integrating relations among the variables in the simultaneous system of equations. The general Johansen test was used and is based on the null hypothesis that there is no co-integration; against the alternative that there is co-integration (Johansen, 1995).

The Johansen test is based on 2 tests, namely, the Trace statistic test and the Maximum Eigen value test. Trace Statistic: $\lambda_{\max }=T \sum_{\rho=\gamma+1}^{N} \ln \left(1-\lambda_{p}\right)$

And the

Eigen value Statistic: $\lambda_{\max }=T \sum_{\rho=\gamma+1}^{N} \ln \left(1-\lambda_{p}\right)$

The conclusion of this was done by taking the majority choice from the maximum Eigen statistics, since both the trace and max-Eigen test statistics are equally efficient. The results of the co-integration test are shown in Table 3.

\section{Empirical Results}

\subsection{Unit Root Test}

The results of unit root test are given in table 1 . 
Table 1. Results of the Augmented Dickey-Fuller Stationarity Test

\begin{tabular}{lllll}
\hline Levels & \multicolumn{2}{l}{ Level } & \multicolumn{2}{l}{ First Difference } \\
\cline { 2 - 5 } & Value & P-value & Value & P-value \\
\hline Lnvalueaddedw & -2.027535 & 0.2748 & -9.133654 & 0.0000 \\
LnGCFW & -1.574042 & 0.4921 & -9.130991 & 0.0000 \\
LnSci & -1.053867 & 0.7314 & -12.50802 & 0.0001 \\
LnArts & -2.375625 & 0.1512 & -12.62204 & 0.0001 \\
\hline
\end{tabular}

Note: Estimates were obtained using the Augmented Dickey Fuller Tests. VALUEADDEDW is value added productivity of labour;GCFW is the

Gross capital Formation per worker; graduates from the arts and science disciplines are represented as Arts\& Sci respectively.

From table 1, all the variables were found to be non-stationary at level but stationary at first difference.

\subsection{Determination of Optimal Lags}

The study determined the optimal lag value using the Akaike Information Criteria (AIC), Schwartz information Criteria (SIC), Schwartz Bayesian Criteria (SC), Hannan-Quinn information criteria (HQ), final prediction error (FPE) and likelihood ratio test (LR). The lower the value obtained under these criteria, the better criterion. The results are shown in Table 2.

Table 2. Results of the Optimal Lag Selection

\begin{tabular}{llllll}
\hline Model & Lag & FPE & AIC & SIC & HQ \\
\hline LNVALUEADDEDW =f(LNGCFW, & 0 & $9.33 \mathrm{e}-05$ & 2.072335 & 2.175275 & 2.114019 \\
LNARTS,LNSCI) & 1 & $9.40 \mathrm{e}-07$ & -2.526227 & $-2.011527^{*}$ & -2.317807 \\
& 2 & $6.87 \mathrm{e}-07^{*}$ & $-2.840931^{*}$ & -1.914470 & $-2.465775^{*}$ \\
\hline
\end{tabular}

Note: VALUEADDEDW is value added productivity of labour;GCFW is the Gross capital Formation per worker; graduates from the arts and science disciplines are represented as Arts\& Sci respectively. Final prediction error (FPE),Akaike information criterion(AIC),Schwarz information criterion (SIC)and Hannan-Quinn information criterion(HQ)

Taking the majority, the optimal lag selectedby FPE, AIC,SIC, and HQfrom Table 2, was2

\subsection{Co-Integration Test}

The variables were tested for co-integration and the results are shown in Table 3.

Table 3. Results of the Co-integration Test

\begin{tabular}{lllllll}
\hline Regression Model & $\begin{array}{l}\text { Data } \\
\text { Trend: }\end{array}$ & None & None & Linear & Linear & Quadratic \\
\cline { 2 - 7 } & $\begin{array}{l}\text { Test } \\
\text { Type }\end{array}$ & $\begin{array}{l}\text { No } \\
\text { Intercept }\end{array}$ & Intercept & Intercept & Intercept & Intercept \\
\cline { 2 - 8 } & & No Trend & No Trend & No Trend & Trend & Trend \\
\hline LNVALUEADDEDW & Trace & 0 & 1 & 1 & 1 & 1 \\
LNGCFW LNARTS LNSCI & Max-Eig & 0 & 1 & 1 & 1 & 1 \\
\hline
\end{tabular}

Note: VALUEADDEDW is value added productivity of labour;GCFW is the Gross capital Formation per worker; graduates from the arts and science disciplines are represented as Arts\& Sci respectively.

There is evidence of co-integration shown by the Juselius-Johansen test of co-integrationas shown it Table 3 .

4.4 Estimation Results for the VECM Analysis

The estimation results for the VECM analysis are shown in Table 4. 
Table 4. Regression Results for Discipline of Graduates

Cointegrating Eq: CointEq1

\begin{tabular}{|c|c|c|c|c|}
\hline LNVALUEADDEDW(-1) & 1.000000 & & & \\
\hline \multirow[t]{3}{*}{ LNGCFW(-1) } & 0.106034 & & & \\
\hline & $(0.08200)$ & & & \\
\hline & [ 1.29313$]$ & & & \\
\hline \multirow[t]{3}{*}{ LNARTS(-1) } & -0.311412 & & & \\
\hline & $(0.06643)$ & & & \\
\hline & {$[-4.68769]$} & & & \\
\hline \multirow[t]{3}{*}{ LNSCI(-1) } & 0.006058 & & & \\
\hline & $(0.08892)$ & & & \\
\hline & {$[0.06813]$} & & & \\
\hline $\mathrm{C}$ & -5.182258 & & & \\
\hline Error Correction: & D(LNVALUEADDEDW) & D(LNGCFW) & D(LNARTS) & $\mathrm{D}(\mathrm{LNSCI})$ \\
\hline \multirow[t]{3}{*}{ CointEq1 } & 0.433030 & -0.183901 & $0.849084 * *$ & 0.232361 \\
\hline & $(0.27658)$ & $(0.18826)$ & $(0.34452)$ & $(0.30782)$ \\
\hline & {$[1.56566]$} & {$[-0.97687]$} & [ 2.46456] & {$[0.75486]$} \\
\hline \multirow[t]{3}{*}{ D(LNVALUEADDEDW(-1)) } & $-0.624223 * *$ & $0.961981 * * *$ & $0.772432 * *$ & $1.242918 * * *$ \\
\hline & $(0.25755)$ & $(0.17530)$ & $(0.32081)$ & $(0.28664)$ \\
\hline & {$[-2.42369]$} & {$[5.48754]$} & {$[2.40773]$} & [ 4.33616] \\
\hline \multirow[t]{3}{*}{ D(LNVALUEADDEDW(-2)) } & $-2.697844 * * *$ & $-0.467502 *$ & $-1.962401 * * *$ & $-1.028788 * *$ \\
\hline & $(0.40268)$ & $(0.27409)$ & $(0.50159)$ & $(0.44817)$ \\
\hline & {$[-6.69967]$} & {$[-1.70566]$} & {$[-3.91232]$} & {$[-2.29555]$} \\
\hline \multirow[t]{3}{*}{ D(LNGCFW(-1)) } & $0.745863 * * *$ & $-0.387132 * * *$ & 0.174496 & 0.189187 \\
\hline & $(0.17752)$ & $(0.12083)$ & $(0.22113)$ & (0.19757) \\
\hline & [ 4.20154] & {$[-3.20392]$} & [ 0.78912] & {$[0.95756]$} \\
\hline \multirow[t]{3}{*}{ D(LNGCFW(-2)) } & 0.263780 & -0.076563 & 0.179443 & 0.097359 \\
\hline & (0.20804) & $(0.14160)$ & $(0.25914)$ & $(0.23154)$ \\
\hline & [ 1.26794$]$ & {$[-0.54069]$} & [ 0.69246$]$ & [ 0.42049] \\
\hline \multirow[t]{3}{*}{ D(LNARTS(-1)) } & $0.349680 * * *$ & -0.011012 & $-0.499516 * * *$ & 0.181757 \\
\hline & $(0.10179)$ & $(0.06929)$ & $(0.12680)$ & $(0.11329)$ \\
\hline & [ 3.43523] & {$[-0.15894]$} & {$[-3.93953]$} & [ 1.60436$]$ \\
\hline \multirow[t]{3}{*}{ D(LNARTS(-2)) } & $0.187174^{*}$ & 0.015633 & -0.174012 & 0.155684 \\
\hline & $(0.10151)$ & $(0.06910)$ & $(0.12645)$ & $(0.11298)$ \\
\hline & [ 1.84382$]$ & [ 0.22625$]$ & {$[-1.37614]$} & [ 1.37798$]$ \\
\hline \multirow[t]{3}{*}{ D(LNSCI(-1)) } & $0.368290 * * *$ & 0.067134 & 0.181037 & $-0.721107 * * *$ \\
\hline & (0.09990) & $(0.06800)$ & $(0.12444)$ & (0.11119) \\
\hline & [ 3.68642] & [ 0.98726$]$ & [ 1.45477$]$ & {$[-6.48543]$} \\
\hline \multirow[t]{3}{*}{ D(LNSCI(-2)) } & $0.204616^{*}$ & 0.051799 & 0.177585 & $-0.362557 * * *$ \\
\hline & (0.11069) & $(0.07534)$ & $(0.13787)$ & $(0.12319)$ \\
\hline & [ 1.84862$]$ & {$[0.68755]$} & [ 1.28803] & {$[-2.94312]$} \\
\hline \multirow[t]{3}{*}{$\mathrm{C}$} & $-0.056879 * *$ & 0.014448 & -0.037270 & 0.000273 \\
\hline & $(0.02574)$ & $(0.01752)$ & $(0.03206)$ & $(0.02864)$ \\
\hline & {$[-2.21000]$} & {$[0.82472]$} & {$[-1.16255]$} & [ 0.00955$]$ \\
\hline
\end{tabular}

Note:Figures denote the coefficients, standard errors(), and t-statistics[]. $\Delta$ denotes first difference,-1 denotes lag 1,-2 denotes lag 2, ln denotes natural Logarithm transformation. *, ** and *** means significant at 10\%, 5\% and 1\% respectively. VALUEADDEDW is value added productivity of labour;GCFW is the Gross capital Formation per worker; graduates from the arts and science disciplines are represented as Arts\& Sci respectively. 
From Table 4, the Error Correction Term(ECT) is shown in equation 10:

$\mathrm{ECT}=$ LNVALUEADDEDW (-1) + 0.106034LNGCFW (-1) -0.311412 LNARTS (-1) + 0.006058LNSCI (-1) $-5.182258$

Here the constant is given by5.182258. This means that the long run deviations from the equilibrium are corrected a $5.2 \%$ rate.

Looking at the target variables inTable 4, graduates from both Arts and Science academic disciplines positively impact value added productivity of labour in the short run; with the impact of science graduates being on average slightly more than that of the arts graduates. This means thatscience graduates are almost as productive as the arts graduates. Also, value added productivity of labour has an impact on both the Arts and Science graduates. This effect had two signs that warranted another test. So the Wald test was done in order to confirm the direction of impact from value added productivity of labour to both Arts and Science graduates.

\subsection{Causality Tests: Wald Test}

The results of the Wald test are shown in Table 5.

Table 5. Results of the Wald Test

\begin{tabular}{|c|c|c|c|c|}
\hline Model & Null Hypotheses & $P$ value & $\begin{array}{l}\text { Decision } \\
\text { at } 5 \%\end{array}$ & Conclusion \\
\hline \multirow[t]{4}{*}{$\begin{array}{l}\text { LNVALUEADDEDW } \\
\text { LNGCFW LNARTS } \\
\text { LNSCI }\end{array}$} & Ho: $\mathrm{C}(6)=\mathrm{C}(7)=0$ & 0.0026 & Reject Ho & $\begin{array}{l}\text { There is short run causality running } \\
\text { from Arts Graduates to } \\
\text { VALUEADDEDW. }\end{array}$ \\
\hline & Ho: $C(8)=C(9)=0$ & 0.0011 & Reject Ho & $\begin{array}{l}\text { There is short run causality running } \\
\text { from Science Graduates to } \\
\text { VALUEADDEDW. }\end{array}$ \\
\hline & Ho: $\mathrm{C}(22)=\mathrm{C}(23)=0$ & 0.0000 & Reject Ho & $\begin{array}{l}\text { There is short run causality running } \\
\text { from VALUEADDEDW to Arts } \\
\text { Graduates. }\end{array}$ \\
\hline & Ho: $C(32)=C(33)=0$ & 0.0000 & Reject Ho & $\begin{array}{l}\text { There is short run causality running } \\
\text { from VALUEADDEDW to Science } \\
\text { Graduates. }\end{array}$ \\
\hline
\end{tabular}

Note: $c(1), \ldots, c(33)$ are coefficients. VALUEADDEDW is value added productivity of labour; GCFW is the Gross capital Formation per worker; graduates from the arts and science disciplines are represented as Arts\& Sci respectively.

From Table 8 , there is short run bi-causality between value added productivity of labour and graduates Arts and Science academic disciplines.

\section{Discussions and Policy Recommendations}

The positive impact of higher education on labour productivity is in agreement with studies elsewhere (e.g., Turyareeba et al., 2018; Gu \& Willox, 2018). The study adds to the labour market literature by applying Value added per worker to measure labour productivity for higher education graduates from both the both Arts and Science academic disciplines. The findings show that graduates from arts, are almost as productive as those from the science-related disciplines. This agrees with Waits (2014) who argues that the importance of arts discipline should still emphasised in the development of a country.

Given the higher enrolments, the Arts graduates cannot be patted on the shoulder. The productivity of arts graduates is highly likely to be due to job mismatches, knowing that many of the Arts graduates are generalists and not professionals (Ntemngweh, 2016; Pseiridis, Lianos,\& Agiomirgianakis, 2018). Secondly, this could be due to the challenge regarding the employability of Arts graduates; that is typical of the labour market in Uganda and other developing countries elsewhere. Therefore, policies to better allocate these graduates in the labour market should be adopted so as to increase their productivity.

The higher education sector should also have more studies of this kind to increase information, related to the productivity of educated labourers, the inter relationships between the sector and other major sector of the economy. Information is the beginning of having solutions to problems. 


\section{Acknowledgements}

The support of the Swedish government, as well as-an outstanding research team is acknowledgement for the success of this study.

\section{References}

Aghion, P., Boustan, L., Hoxby, C., \& Vandenbussche, J. (2009). The causal impact of education on economic growth: evidence from US. Brookings papers on economic activity, 1, 1-73.

Antonelli, C., \& Fassio, C. (2015). Academic knowledge and economic growth: are scientific fields all alike?. Socio-Economic Review, 14(3), 537-565. https://doi.org/10.1093/ser/mwv025

Assaad, R., \& Abdalla, D. (2018). The humanities as the default option in higher education: the case of Egypt. The Changing Face of Higher Education, 69-91. Routledge. https://doi.org/10.4324/9781315276601-4

Borisova, A. (2019, January). The Employment of Graduates by the Profession: Factors of Effectiveness. International Scientific Conference" Far East Con"(ISCFEC 2018). Atlantis Press. https://doi.org/10.2991/iscfec-18.2019.2

Bridgstock, R. (2019). Graduate employability 2.0: Learning for life and work in a socially networked world. Education for Employability, 1, 97-106). Brill Sense. https://doi.org/10.1163/9789004400832_008

Byrne, D. M., \& Corrado, C. A. (2017). ICT Services and their Prices: What do they tell us about Productivity and Technology? https://doi.org/10.17016/FEDS.2017.015

Chaudhary, A. R., Iqbal, A., \& Gillani, S. Y. M. (2009). The nexus between higher education and economic growth: An empirical investigation for Pakistan. Pakistan Journal of Commerce and Social Sciences, 3(1), 1-9. https://doi.org/10.3923/pjssci.2010.1.7

Dalmon, D. L., Fonseca, I., Avena, C. P., Carnoy, M., \& Khavenson, T. (2019). Do students make greater achievement gains in some higher education institutions' programs than others? Insights from Brazil. Higher Education, 1-24. https://doi.org/10.1007/s10734-019-00376-6

De Grip, A., Van Loo, J., \& Mayhew, K. (2002). The economics of skill obsolescence: theoretical innovations and empirical applications. Research in Labour Economics, (21), 1-26. https://doi.org/10.1016/S0147-9121(2002)21

Grinis, I. (2019). The STEM Requirements of "Non-STEM" Jobs: Evidence from UK Online Vacancy Postings. Economics of Education Review. https://doi.org/10.1016/j.econedurev.2019.02.005

Gu, W., \& Willox, M. (2018). Productivity Growth in Canada and the United States, Recent Trends and Determinants.

Hanushek, E. A., \& Woesmann, L. (2007). The role of education quality for economic growth. World Bank Policy Research Working Paper, (4122). https://doi.org/10.1596/1813-9450-4122

Johansen, S.(1995). Likelihood-Based Inference in Cointegrated Vector Auto Regressive Models. Advanced Texts in Econometrics, Oxford University Press Inc, NewYork. https://doi.org/10.1093/0198774508.001.0001

Juselius, K. (2006). The cointegrated VAR model: methodology and applications. Oxford university press.

Kiani, A. (2011). Role of university education in poverty alleviation in Pakistan. Interdisciplinary Journal of Research and Business, 1(7) 30, 38.

Kui, L. (2006). The interactive causality between education and economic growth in China. Working Paper Series.

Marx, K. (2000). Theories of surplus value: Books I, II, and III. Amherst. NY: Prometheus Books.

Ministry of Education and Sports (MES). (2017). Education and Sports Sector Fact Sheets 2000-2016. Kampala, Uganda.

Moeller, J. O. D. (2018). Productivity redesigned.

Morrissey, S. (2013). The value of a Liberal Arts Educaation. Philosophyy, Politics, and Economics Undergraduate Journal, 8.

Musisi, N. B., \& Muwanga, N. K. (2003). Makerere University in Transition 1993-2000, Opportunities and Challenges. Oxford: James Currey; Kampala: Fountain Publishers, 9-15. 
Ntemngweh, P. (2016). Education-job mismatch among university graduates in Cameroon: The perspectives of graduates in the field of humanities (Master's thesis).

Pelser, A.C. (2016). Philosophy, Politics, and the end of liberal Arts Education. Christian Research Journal, 39(4).

Pitan, O. S., \& Adedeji, S. O. (2012). Skills Mismatch among University Graduates in the Nigeria Labor Market. Online Submission.

Pseiridis, A., Lianos, T. P., \& Agiomirgianakis, G. (2018). Overeducation of University Graduates: A Voluntary and Rational Choice of Individuals-The Case of Three Greek Universities. Theoretical Economics Letters, 8(11), 2135. https://doi.org/10.4236/tel.2018.811140

Solow, R. M. (1957). Technical change and the aggregate production function. The review of Economics and Statistics, 312-320. https://doi.org/10.2307/1926047

The National Council for Higher Education (NCHE). (2016). The state of higher education and training in Uganda 2013/14. A Report on higher education delivery and institutions.

Turyareeba, D., Kateregga, E., Hisali, E., Muvawala, J., \& Abaliwano, J. (2018). Determinants of Total Factor Productivity Growth in Africa. ORSEA JOURNAL, 7(2).

Yurtkuran, S., \& Terzi, H. (2015). Does Education Affect Economic Growth in Turkey? A Causality Analysis. Dokuz Eylül Üniversitesi İktisadi ve İdari Bilimler Fakültesi Dergisi, 30(2).

Waits, M. J. (2014). Five roles for arts, culture, and design in development. Community Development Investment Review, (02), 017-023.

Wamboye, E., Adekola, A., \& Sergi, B. S. (2015). Internationalisation of the campus and curriculum: evidence from the US institutions of higher learning. Journal of higher education policy and management, 37(4), 385-399. https://doi.org/10.1080/1360080X.2015.1056603

World Bank. (2018). World Bank Open data - World Bank Group. 